\title{
ESTRANGEIROS RESIDENTES: UMA FILOSOFIA DA MIGRAÇÃO
}

\author{
Resident Foreigners: A Philosophy of Migration
}

\author{
DI CESARE, Donatella. \\ Belo Horizonte: Ed. Âyiné, 2020. 356p.
}

Otávio Ávila*

Lançado em 2020 no Brasil, Estrangeiros Residentes: Uma filosofia da migração é uma resposta importante e socialmente imersiva a respeito do fenômeno migratório do século XXI sugerida pela filósofa italiana Donatella Di Cesare. Nas 356 páginas, a autora apresenta uma gama extensa de pensadores do fenômeno, incluindo aqueles que produziram suas obras envolvidos pessoalmente pela experiência migratória num conjunto de reflexões que Peter Burke (2017) denominou de "teoria do exílio".

Como filósofa, a principal contribuição trazida no livro por Di Cesare está na amplitude do pensamento que coloca em xeque a perspectiva estadocêntrica do mundo. Ainda que a base das reflexões esteja dirigida aos dilemas contemporâneos do continente europeu, o livro amplia sua importância extraterritorial ao não abdicar do atual contexto globalizado. Como linha reflexiva, encontram-se a ciência política e a filosofia política datadas da Antiguidade e da pré-modernidade, de modo que questões que atravessam a história humana, como a hospitalidade e a comunidade, sejam analisadas por um caminho mais amplo do que a circunstância do presente. Afinal, essa parece ser uma necessidade de toda proposta filosófica do fenômeno migratório: a da amplitude espaço-temporal que fundamenta o desejo e a necessidade da própria espécie em se deslocar.

Essa cultura da espécie aparenta ser uma das justificativas da autora ao antagonizar com o sistema das fronteiras dos Estados-nação como uma contraprodução da vida, especialmente explorada na primeira das quatro partes que estruturam o livro. Já na capa, a edição da Âyiné utiliza uma parte do texto para descartar a hipótese levantada pela política diplomática em encontrar "soluções"

Doutorando em Comunicação e Cultura pela Universidade Federal do Rio de Janeiro (UFRJ). Rio de Janeiro, RJ, Brasil. E-mail: ota_cez@hotmail.com. Orcid: https://orcid.org/0000-0002-64956226. 
de "controle de fluxos" ou mesmo "integrar" os refugiados. O leitor que procura soluções de gestão para este tema milenar e suas decorrentes problemáticas se decepcionará porque, ao contrário, encontrará mais interrogações, um caminho longo a se percorrer e um fim quase utópico sobre "coabitar no terceiro milênio", que dá nome à quarta e última parte do livro. Trata-se de uma obra crítica às burocracias estatal e acadêmica que colocam sob o mote da jurisdição e dos acordos todas as respostas.

Quanto ao seu título, cabe explicá-lo em duas partes. "Estrangeiros residentes" é a designação crítica ao sistema estadocêntrico de governança mundial. Durante o livro, Di Cesare evoca a mesma concepção de provisoriedade do estrangeiro e, ao colocá-lo como residente, advoga por um habitar comum onde não haveria distinção entre autóctones e estrangeiros, dispensando assim a necessidade de asilo ou hospitalidade. Este conceito é explorado com base na filosofia de Lévinas (2008) e Derrida (2003), segundo os quais a hospitalidade seria a baliza condutora da própria ética a partir de um sujeito que reconheça que é o próprio acolhimento a condição da existência do eu; sujeito este contrário ao tipo soberanista, pleno de si e acusado por ela de ser o aniquilador das diferenças culminantes dos totalitarismos do século XX.

A perspectiva quase utópica de Di Cesare sobre o habitar baseada nessa hospitalidade incondicional é antes originada pela concepção de Jerusalém, em total oposição à autoctonia de Atenas, e toma como base a historicidade dessas cidades, na qual a Cidade Santa é formada pelo gher (o estrangeiro no judaísmo), um residente que habita. Mas se Atenas também mantinha estrangeiros em seu território, qual a diferença entre ambas? Aristóteles explica que a residência não deveria garantir cidadania em prol da estabilidade política da polis, enquanto Jerusalém teria como critério o habitar.

Aí reside um ponto-chave e que aponta para a segunda parte do título. A filosofia da migração proposta pela autora está associada à fenomenologia do habitar de Heidegger. O estrangeiro como figura híbrida, fugaz, concebe um habitar que "confirma uma relação outra com a terra, remete a um modo outro de ser no mundo [...] Habitar significa permanecer no estrangeiro" (p. 258). Ou seja, não se trata do verbo ligado à habitação como moradia e apropriação da terra, como enraizamento do corpo autóctone, mas um habitar que se realiza justamente na passagem e que, consequentemente, pensa na estadia do homem sobre a terra. A quebra do habitar como ter (ideia de posse) para o ser-aí, o ser-no-mundo (o Dasein heideggeriano) implica olhá-lo como "traço fundamental da existência" (p. 226), na qual os migrantes ocupariam o centro das reflexões sobre o próprio homem, existencialmente sempre estrangeiro para si mesmo (Kristeva, 1994).

Essas reflexões que encaminham para as conclusões do livro, antes, precisam ser contempladas por outra referência da filosofia da migração, a qual Di Cesare compreende ter sido a primeira a sistematizar o campo. Ao escrever 
Nós, os Refugiados, Hannah Arendt colocou pela primeira vez o sujeito deslocado em primeira pessoa, conferindo-lhe voz, lado e perspectiva que ainda hoje suscitam críticas aos sistemas de informação e comunicação no que diz respeito à famigerada "crise migratória". Sua filosofia já evocava a questão do habitar ligada à hospitalidade - ao analisar a apatridia como a grande questão política da modernidade, onde "a novidade não é ser expulso, mas não encontrar abrigo no mundo" (p. 66).

Na parte final, Di Cesare traz situações contemporâneas, como as mortes em Lampedusa e a do menino Aylan Kurdi. É perceptível a relação da questão com sua crítica à sociedade de consumo, que trata o migrante como excesso a ser coibido pelo passaporte, que pode ser barreira ou bilhete de entrada para os turistas ricos. A comunidade é outro conceito importante ao fim porque o pertencimento a ela pode se tornar um negador de diferenças. Cuidadosa a essa dimensão tanto quanto à recusa comunitária que levaria à governança de um Estado Mundial, ela invoca a comunidade como lugar privilegiado da construção de um comum humano, não apropriável e que retira o "nós" para o "ser-com". Eis aqui a chave para o coabitar. E o que é ele, então? "Não se trata de um rígido estar um ao lado do outro. Em um mundo invadido pela ocorrência de tantos exílios, coabitar quer dizer compartilhar a proximidade espacial em uma convergência temporal em que o passado de cada um passa a ser articulado com o presente comum tendo em vista um futuro também comum" (p. 351).

\section{Referências bibliográficas:}

BURKE, Peter. Perdas e Ganhos: Exilados e expatriados na história do conhecimento na Europa e nas Américas, 1500-2000. São Paulo: Unesp, 2017.

DERRIDA, Jacques. Anne Dufourmantelle convida Jacques Derrida a falar Da Hospitalidade. Entrevistadora: Anne Dufourmantelle. São Paulo: Escuta, 2003.

DI CESARE, Donatella. Estrangeiros Residentes: Uma filosofia da migração. Belo Horizonte: Âyiné, 2020.

HEIDEGGER, Martin. Ser e Tempo. Petrópolis: Vozes, 2015.

KRISTEVA, Julia. Estrangeiro para nós mesmos. Rio de Janeiro: Rocco, 1994.

LÉVINAS, Emmanuel. Totalidade e infinito. São Paulo: 70, 2008. 